\title{
Power, politics and the Turkish labour union elite
}

\begin{abstract}
In the context of the EU-Turkey negotiations, the role of the social partners in Turkey is gaining in importance, but basic knowledge about the partners is lacking. The research study reported in this article tries firstly to draw a socio-demographic picture of the Turkish labour elite in the light of Robert Michels's 1915 'iron law of oligarchy'. Secondly, the relations between the Turkish labour confederations and the political parties are researched. The results confirm, at least in part, Michels's theory. We may observe a maturation of the confederations and an institutionalisation of power. We may also observe differences in the professionalisation of the elites. However, sector (public or private) seems to be a more important factor in explaining the differences. Next, the research study roughly confirms the traditional relationships between parties and confederations. Türk-Iss would be most aligned to CHP, Hak-Iş to AKP, and DISK to the numerous parties of the left. In the public sector, KESK seems to be closely aligned to ÖDP and BDP, Kamu-Sen to MHP, and Memur-Sen to SP and AKP.
\end{abstract}

Keywords: Turkey, labour unions, elites, power, Turkish political parties

\section{Introduction}

Long before the European Union (EU) opened accession negotiations in 1999, Turkey was already a hot item in public and political debate around Europe. Despite this high level of genuine interest in the country, its politics and society (and the mass tourism), knowledge about Turkey is fragmented and unsatisfactory. Co-operative and structured industrial relations are crucial in most EU economies and so the negotiation talks have focused on the development of social dialogue in Turkey. This has led to reforms and the establishment of several tripartite institutions that should guarantee the defence of both workers' and employers' interests. However, attention is hardly ever focused on the internal functioning of the actors in industrial relations, such as employer organisations and labour unions; only Arslan et al. (2004) have researched labour union management as a part of the Turkish power elite.

This study seeks to make a contribution to the academic analysis of the leadership and internal organisation of Turkish labour unions functioning in a sometimes hostile and difficult environment. Faced with a stunning lack of basic knowledge, the study concentrates on gathering and analysing basic socio-demographic and political data on the leadership of Turkish labour unions. It analyses the data using the years-old 'Iron law of Oligarchy', as developed by Michels (1915). Secondarily, this study is aimed at objectifying societal perceptions of the links between union confederations and political parties. Clarifying this could contribute to both the academic and practical comprehension of the Turkish social dialogue. 
In the first section, we discuss the context of labour unions in Turkey, following which we develop our theoretical guidelines. In the third section, we discuss the research in publication, so as to continue in the fourth with the analysis of the data collected on the socio-demographics of Turkish labour union leaders. The fifth section discusses the links between politics and unions and in the sixth we conclude.

\section{The Turkish labour elite and Turkish labour unions}

The history of Turkish labour unions started in 1952 with the establishment of Türkİş, the first labour union confederation of Turkey (Zurcher, 2006: 285). The almost sixty-year history of Turkish syndicalism reads as a story of struggling, gaining power and being catapulted backwards since, on three occasions, Turkish politics and society were disrupted by military interventions. These interventions all had their effect on trade unionism with the climax being the 1980 coup, which was directly oriented at countering the power of the labour unions (Asp, 2002). Two main unions, respectively on the far right and far left of the political spectrum, MISK (Milliyetçiler Işçi Sendikaları Konfederasyonu) and DISK (Devrimci Işçi Sendikaları Konfederasyonu), were banned and the leadership of the labour movement was hit hard. After the 1980 intervention, union freedoms were regained step-by-step, even though subsequent governments have intervened in Turkish industrial relations in the attempt to weaken the labour unions (Yildirim and Calis, 2006).

Labour organisations got through the aftermath of the 1997 military intervention relatively unscathed, but have a hard time resisting the effects of large-scale privatisation and the 2001 financial crisis. EU accession talks are, however, currently contributing to the official recognition of labour unions as important actors in Turkish society, although the labour unions themselves are struggling to stabilise and deepen their influence in Turkish companies.

Three main confederations have developed their organisations and dominate the field in the private sector: Türk-İş; DISK; and Hak-İş. As recently as 1995, a crucial reform of the Turkish law gave public employees the right to form unions. This paved the way for the formation of several new unions and their confederations. The public sector is dominated by three large unions: Kamu-Sen; Memur-Sen; and KESK (Kamu Emekçileri Sendikaları Konfederasyonu).

The three major private sector and public sector union confederations have been selected for this research as they indisputably form the core of Turkish unionism. Most academic studies exclude the more recently-founded confederations in the public sector (Yildirim, Calis and Benli, 2008), but this research has opted to include them since, based on their reported numbers of members, they are almost as big as the private sector confederations. Furthermore, judging by the public debate, the public sector unions seem to be able effectively to influence civil society and politics.

In order to put the results of the research into context, this article briefly addresses the history of the confederations we researched. Türk-İş is the eldest and biggest labour confederation in Turkey, with over two million members. The confederation was founded in 1952 with the support of the ICFTU (International Confederation of Free Trade Unions) (Zurcher, 2006: 285). It therefore took the American style of unionism as its example and was very averse to any alliance with a political ideology or party. It 
tried to keep itself above the parties (parti üstünde) and this apolitical orientation continues to influence the confederation's strategy (Blind, 2007). Even so, Türk-İş is today a very pragmatic labour union that has the image of being close to the state and the power source (Uçkan, 2007). It is sometimes overtly nationalist and has the ultra-nationalist Türk-Metal union as one of its members. Politically, it is close to parties like CHP (Cumhuriyet Halk Partisi) and MHP (Milliyetçi Halk Partisi), although the actual President of Türk-İş, Mustufa Kumlu, has a reputation of being close to AKP (Adalet ve Kalkınma Partisi) (Türk-İş baskanlik yarisini Kumlu kazandi, 2007).

The second and third biggest labour confederations are DISK and Hak-İş, each of which have around 400000 members. DISK was founded in 1962 by sectoral unions which had left Türk-İş due to its apolitical character. DISK is an openly left-wing, militant confederation and therefore faces regular intimidation by the state. In the aftermath of the 1980 military coup, DISK was banned - a suspension which continued until 1992. This long period of interdiction made it difficult for DISK to restart its activities, as most of its members and cadres had retired (Alemdar, 2009). In recent years, DISK seems to have left behind the sometimes violent activism of the past (Yildirim, Calis and Benli, 2008).

Hak-İs, founded in 1976, was created by Necmettin Erbakan and his national outlook movement (milli görüs) in an attempt to gain more support within the labour class (Duran and Yildirim, 2005). Its obvious affiliation and subordination to MSP (Milli Saadet Partisi) led to its relative unpopularity. Due to the prolonged interdiction of DISK after the eighties coup, Hak-İs was saved from silent demise by the influx of exDISK affiliates that did not want to join the Türk-Iss or MISK unions. Nowadays, Hakİş has changed its identity and has left behind its corporatist ideas of a union between labour and capital. It now has a pro-capitalism and pro-privatisation identity, seeking to defend workers' interests in a pragmatic way with a conservative and rather religious background (Blind, 2007; Duran and Yildirim, 2005; Yildirim, Calis and Benli, 2008). Politically, it aligns itself with the conservative religious parties, such as AKP and SP (Saadet Partisi) (Duran and Yildirim, 2005).

The three major confederations of the public sector are Kamu-Sen, Memur-Sen and KESK. All of them have been founded more recently, around 1995 since, before 1992 , the unionisation of public employees was forbidden.

Kamu-Sen is the biggest and the eldest, and has the image of being nationalist and state-oriented.

Until recently, KESK was the second biggest. KESK is closely aligned to the left of the political sphere and is commonly known for its activism. It faces regular intimidation from the government with the imprisonment of its members and managers (14 KESK Trade Unionists Arrested, 2009). KESK is the only one of the three public service confederations that is internationally aligned, to the European Trade Union Confederation (ETUC).

Memur-Sen was founded in 1995 as a rather small union, but has managed to expand continuously until it recently outgrew KESK. It has a more conservative and religious identity and was founded in order to improve economic efficiency by limiting conflicts between capital and labour and by defending the moral values of society (Trade Unions in Turkey, 1998). 
These labour organisations are all trying to organise and defend workers in an environment that is often hostile. First, there is the state's predominance in all institutions related to social dialogue. These institutions, created under the pressure of the EU (Sural, 2007; Sural, 2006), are often confrontational due to their tripartite structure and the de facto domination of the state (Rychly and Vylitova, 2005; Yildirim and Calis, 2006). This is partly historic and even supported by the social partners themselves.

Second, the state strictly organises the functioning of labour organisations. In order for a labour union to be eligible to negotiate and sign collective agreements, it needs to have at least $50 \%$ of workers in the company as members and at least $10 \%$ of workers in the sector at the national level (Katsu et al. 2006). This regulation obviously supports the creation of 'yellow' unions and undermines competition between the different unions as it positively discriminates in favour of the dominant unions and their confederation, Türk-İss. Next to that, militants that want to take on an elected function in a labour organisation need at least ten years of experience while, to join a labour union, an official notarised act is required. Even the internal organisation of unions is regulated by Turkish law (No. 2821). A confederation can be founded by at least five sectoral unions; it has to consist of several bodies with powers which are determined by the legislature; while a government representative has the right to assist in general assemblies.

Third, the structure of the Turkish economy is not open to a strong and redistributive labour movement. The export-oriented, liberal economic model implemented after the 1980 coup opened Turkey up to international competition, putting pressure on labour conditions. This, combined with the huge power of the several industrial holdings that control considerable parts of Turkey's economy, makes it difficult for unionism to develop towards being a stable, powerful actor in Turkish society.

\section{Hypotheses}

In discussing power in organisations, the monumental theory and work of Robert Michels (1915) cannot be omitted. Recent work and theories on organisational sociology provide us with more modern approaches to leadership and organisations, but this research study chose to take this years-old theory as its theoretical foundation for several reasons. First, Michels's theory, which can be placed in the 'elite' research tradition, is still seen as one of:

If not the only, truism in contemporary political science. (McClelland, 1996: 580)

Next, Michels's work has often been reduced to its core affirmation, the iron law of oligarchy, which states that:

It is organization which gives birth to the dominion of the elected over the electors, of the mandatories over the mandators, of the delegates over the delegators. Who says organization, says oligarchy. (Michels, 1915: 241) 
This is undeniably the core of his work, but this sentence does not encompass the entire theory. In his study of leadership in the German social democratic party, Michels saw that, with the maturisation of the party, an oligarchy developed. This happened essentially through the process of professionalisation and the differentiation of the ruling elite (Coupasson and Clegg, 2006: 328). Regarding professionalisation, Michels (1915) saw that numerous rules and procedures were developed in order to put barriers and distance between the leaders and the rank and file. The leaders became 'indispensable' for the organisation because of their technical knowledge. They thus became more educated and developed skills that were almost absent in the population of the organisation's members. They stabilised their power, tried to hold off competitors and thoroughly selected their successors, who were even more 'professional' and, thus, different from the population than they were.

Finally, we may see that Michels's theory is still regularly applied in research (Leach, 2005; Voss and Sherman, 2000).

According to this theory, with the passing of time and the increasing maturation of an organisation, the oligarchy should show signs of increasing professionalisation and a differentiation from the population. This, therefore, is the guiding hypothesis of the research:

Hypothesis 1: In mature organisations, the leadership will be more professional and thus more differentiated from its population of members.

A second subject addressed in the research is the political affiliation of unions. Many academic authors present Turkish unionism as highly politicised and its leaders as being more interested in their individual political careers than in the genuine defence of the interests of workers. There is a legal ban (under Art. 13 of the Constitution) on the existence of structural links between political parties and unions but, in the popular conception, all labour confederations have outspoken political identities. DISK and KESK are generally seen as (extreme) left-wing organisations, while KESK is regarded as being close to the Kurdish parties. Kamu-Sen \& Türk-İş are, in turn, seen as conservative right-wing unions: they have long been very close to the secularist elite of Turkey, although they pretend to be above politics and declare their neutrality. Finally, Hak-İs and Memur-Sen are generally associated with the muslim-conservative parties of Turkey, AKP and SP. Our second hypothesis is constructed on these popular beliefs:

Hypothesis 2: DISK and KESK are affiliated to left-wing parties; Türk-İş \& KamuSen to right-wing, secular parties; and Hak-İş \& Memur-Sen to muslim-conservative parties.

\section{The research}

In order to test the hypothesis, researchers on the study approached the Turkish labour 'elite', defined as the members of the management committees of the six largest Turkish labour union confederations after 1990. In co-operation with TÜSTAV (Türkiye Sosyal Tarih Araştırma Vakfi) and the different labour confederations, an inventory of the population was made and a total of 169 individuals selected. Some of the confederations did not have official management committees at that time, so we selected members from the official foundation of the confederation. 
Firstly, the confederations were contacted and personally visited in order to explain the research study and to seek co-operation. Some months later, these contact points were sent a survey, an explanatory letter and a list of people who should be surveyed. This strategy led to a disappointing level of response, which resulted in a change of approach with the authors liaising with industrial unions directly and personally contacting some members. The combination of these strategies led to a response rate of $20 \%$. Many members of the survey population were part of the national elite, or had already passed away, so a parallel strategy of information gathering was foreseen. Thorough analyses of the popular and academic literature eventually led to partial answers to our questions from about $41.1 \%$ of the population. Ultimately, information was gathered from $60.7 \%$ of the available population, with more than $50 \%$ of the population from each separate confederation.

\section{Results}

\section{Maturity of the organisation}

To evaluate the maturity of the six confederations, the following indicators are used: size; age; and the institutionalisation of power in the organisation. Whereas Michels (1915) saw the institutionalisation of power as one of the essential outcomes of maturation, here it is used as an indicator of it. This is because, on the one hand, it is generally accepted that maturation indeed leads to institutionalisation; while, on the other, it gives us the possibility of checking whether the three indicators of 'maturity' correlate with each other, which contributes to the validity of the results.

The data is shown in Table 1; for DISK, two dates of foundation are indicated. Historically, DISK was created in 1967 but its functioning was prohibited for over ten years following the 1980 military intervention. This seriously disrupted the organisation to the extent that one of the first reunions in 1992 concluded that:

Unionization in general had severely declined, the former union cadres had almost disappeared, and most of their former members were retired or otherwise withdrawn from the labour market (...). (Alemdar, 2009: 16)

Therefore, it seems better to take 1992 as the actual date of foundation. In the following analyses, relationships will be checked for both foundation dates. 
Table 1 - Age and size

\begin{tabular}{|l|l|l|}
\hline Confederation & Members & Foundation date \\
\hline Türk-İş & 2230015 & 1952 \\
\hline Hak-İş & 418424 & 1976 \\
\hline DISK & 422785 & $1967 ; 1992$ \\
\hline Kamu-Sen & 357841 & 1992 \\
\hline Memur-Sen & 314701 & 1995 \\
\hline KESK & 223460 & 1995 \\
\hline
\end{tabular}

Source: Labour Statistics 2008

In addressing the question of power stability in the different labour confederations, we focus on two principal indicators. First, the amount of rotation in the management councils of the different confederations; and, second, the number of years that labour organisation-managers stay in power. In Table 2, we can obviously see that rotation (N) in Türk-İş and Hak-İş is lower than in the other confederations, although the selection period is longer for them since the public sector confederations and DISK had post-1990 foundation dates. The mean and median years that someone stays in power is also considerably higher in Türk-İş and Hak-İş.

Table 2 - Institutionalisation of power

\begin{tabular}{|l|l|l|l|l|}
\hline Confederation & $\mathbf{N}$ & Mean & Median & Std. Dev. \\
\hline Türk-İş & 13 & 6.46 & 7.00 & 3.503 \\
\hline Hak-İş & 13 & 8.92 & 7.00 & 5.346 \\
\hline DISK & 36 & 3.39 & 2.00 & 1.946 \\
\hline Kamu-Sen & 30 & 5.73 & 5.00 & 1.660 \\
\hline Memur-Sen & 42 & 2.12 & 2.00 & 1.517 \\
\hline KESK & 34 & 3.21 & 3.00 & 1.647 \\
\hline
\end{tabular}

If we now analyse the relationships between these three variables (date of foundation, size and institutionalisation of power), we can find statistically significant relations (at the 0.01 level) between, firstly, the age and size of the union $(r=0.934)$; secondly, between age and the years of functioning of the managers $(r=0.423)$; and thirdly, between size and the years of functioning of the managers $(r=0.257)$. The first, and strongest, relationship is largely explained by the presence of Türk-İş, which is by far the eldest and largest union confederation in Turkey. Next to that, the data show us that, the older the Turkish union confederation, the more likely it is to have a stable leadership. This confirms Michels's iron law of oligarchy. 
The iron law of oligarchy is confirmed by another statistically significant relationship, i.e. between the amount of years a manager stays in power and the year that he or she started functioning in the management committee. A certain part of the population has been excluded from this analysis in order not to distort the results: those that are presently still in power, and have been there for less than four years, have thus been excluded. This relationship is rather weak $(r=0.329)$, but it is statistically significant at the 0.01 level. It thus seems that the newer generations of leaders have the tendency to stay in power longer, but there is thus a stabilisation of power across the population as a whole.

Looking at the evolution of the institutionalisation of power inside the individual confederations, we can see that the situation of Türk-İş \& Hak-İş is relatively stable. The leaders tend to stay in their positions for a relatively long period and this did not change over the period under study. Regarding DISK, we can see that, over time, leaders tend to stay in their position longer, leading to a stability of power in DISK and a tendency to converge with the situation in the other private sector confederations.

In the public sector, the stability of power is far lower than in the private sector confederations. Kamu-Sen has the most stable leadership and there is a positive evolution over time. KESK's leadership shows a negative evolution regarding leadership stability, while Memur-Sen has a very unstable leadership but one which tends towards stability over time.

\section{Professionalisation}

To evaluate the professionalisation of the Turkish labour elite, the research focused on two distinctive concepts. First, the level of education of the elite members; and, second, the career patterns of the managers of the different confederations.

\section{Education}

In terms of education, the differences between the confederations are large and telling. In Table 3, the results and response rates are shown. They clearly show the relatively low level of education of the managers of Türk-İş and Hak-İş, where most people do not hold university degrees. In Memur-Sen and Kamu-Sen, on the contrary, a university degree is almost the minimum level of education of the managers. The two 'leftish' confederations, DISK and KESK, have a more diverse leadership. 
Table 3 - Level of education among union elites

\begin{tabular}{|l|l|l|l|l|l|l|l|}
\hline & Primary & Secondary & $\begin{array}{l}\text { Superior } \\
\text { secondary }\end{array}$ & $\begin{array}{l}\text { Profes- } \\
\text { sional } \\
\text { bachelor }\end{array}$ & $\begin{array}{l}\text { Academic } \\
\text { bachelor }\end{array}$ & Master & Phd \\
\hline Türk-İş $69 \%$ & & $33.3 \%$ & $66.7 \%$ & & & & \\
\hline Hak-İş $54 \%$ & & & $71.4 \%$ & $14.3 \%$ & $14.3 \%$ & & \\
\hline DISK $42 \%$ & $13.3 \%$ & $26.7 \%$ & & $6.7 \%$ & $53.3 \%$ & & \\
\hline $\begin{array}{l}\text { Kamu-Sen } \\
46 \%\end{array}$ & & & & & $85.7 \%$ & $7.1 \%$ & $7.1 \%$ \\
\hline $\begin{array}{l}\text { Memur-Sen } \\
64 \%\end{array}$ & & & $7.4 \%$ & & $88.9 \%$ & $3.7 \%$ & \\
\hline KESK 47\% & & & $25.0 \%$ & $37.5 \%$ & $37.5 \%$ & & \\
\hline
\end{tabular}

Primary education: ilkokul; secondary education: ortaokul; superior secondary education: lise; professional bachelor: 2 years of lisans; academic bachelor: 4 years of lisans; master: lisansüstü; Phd: doctorat

These differences can be explained by several factors. First, it is a matter of the sector in which the confederation is organised. Workers in the public sector are, in general, more highly educated than workers in the private sector, while the teaching unions also have a significant amount of influence in the public sector confederations.

Second, there seems to be a relationship with the 'age' of the organisation. The two eldest confederations, Türk-İş and Hak-İş, have managers which are educated to a far lower level than the newer confederations. This observation is statistically confirmed, as we found a statistically significant relationship at the 0.01 level between the years of education of managers and the foundation date of the confederation. On the understanding that DISK was founded only in 1992, this relation is $r=0.481$; on the understanding that DISK was founded in 1967 , this relation is somewhat stronger, $r=0.586$.

That this relationship is positive is remarkable. The theory of Michels predicts a negative relationship in which the elder, more stable confederations would have more educated managers. This does not seem applicable to the Turkish reality. Also, the data did not show a statistically significant relationship between the level of education and the year a manager started operating as the head of the confederation. Consequently, we cannot say that the level of education is growing among the Turkish labour elite.

\section{Careers}

Differences in career patterns can be revelatory for analysing the 'professionalisation' of an organisation. A union in which the leaders are rank-and-file members that have struggled their way through the multiple levels of a syndical organisation are regarded as less professional, in Michels's view, than unions in which the leadership comes from outside the organisation and is parachuted into the union at the top level. Looking at several indicators, such as 'the age they joined the union', 'the age they started working', 'the age they started as a manager of the confederation' and whether 
or not they performed tasks or functions at lower levels in the organisation, we can try to assess these different career patterns.

Table 4 - Careers of union management

\begin{tabular}{|l|l|l|l|l|l|l|}
\hline \multirow{2}{*}{ Türk-İş } & Mean & 19 & W & F & Diff W/F & Diff U/F \\
\cline { 2 - 7 } & Median & 18 & 23.4 & 48.6 & 29.6 & 25.2 \\
\hline \multirow{3}{*}{ Hak-İş } & Mean & 17.6 & 23.9 & 42.5 & 24.9 & 18.6 \\
\cline { 2 - 7 } & Median & 18 & 22 & 43 & 25 & 21 \\
\hline \multirow{2}{*}{ DISK } & Mean & 17.6 & 22.5 & 48.7 & 31.1 & 26.2 \\
\cline { 2 - 7 } & Median & 16 & 21.5 & 48 & 32 & 26.5 \\
\hline \multirow{3}{*}{ Kamu-Sen } & Mean & 21 & 26.9 & 44.2 & 23.2 & 17.3 \\
\cline { 2 - 7 } & Median & 21 & 32 & 46 & 25 & 14 \\
\hline \multirow{3}{*}{ Memur-Sen } & Mean & 20.8 & 30.9 & 42.8 & 22 & 11.9 \\
\cline { 2 - 7 } & Median & 21 & 32 & 42.5 & 21.5 & 10.5 \\
\hline KESK & Mean & 18.9 & 27.1 & 42.4 & 23.5 & 15.3 \\
\cline { 2 - 7 } & Median & 19 & 23 & 43 & 24 & 20 \\
\hline Total & Mean & 19.4 & 26.8 & 44.7 & 25.3 & 17.9 \\
\hline st. dev & & 3 & 3.3 & 6.9 & & \\
\hline min/max & $10 / 30$ & $17 / 47$ & $30 / 66$ & & \\
\hline
\end{tabular}

$W:$ age the respondent started working; $U$ : age the respondent joined the union; $F$ : age the respondent started the management function

The data show evidently that the managers of private sector confederations have more grassroots careers than the managers of public sector confederations. Nevertheless, some interfering factors have to be taken into account. First, we have to consider differences in education: the managers of public sector confederations that are, in general, more educated, logically start to work later and, thus, also join the union at a later point. Second, the age at which the managers of public sector confederations joined unions may also be influenced by unionism in the public sector being illegal before 1992.

Taking these remarks into account, and looking at the differences between the age they started working on the one hand and the age at which they assumed the function of manager on the other, we see that it is Türk-İs and DISK that seem to have managers with the most grassroots careers. Concerning the difference between the age they joined the union and the age at which they became manager, the major divide is between the confederations of private and public sectors, and this can be explained by the reasons cited already. In the private sector, Hak-İs seems to be the exception, with slightly more 
atypical careers; and, in the public sector, KESK is exceptional with considerably more grassroots career patterns for its managers. Indeed, the managers of Kamu-Sen and Memur-Sen seem to have very atypical careers: according to our data, $77 \%$ of the managers of Kamu-Sen and $52 \%$ of the managers of Memur-Sen never performed a function at sectoral or regional level before becoming a manager at national level.

\section{Gender, ethnicity and religion}

The research study also zoomed in on other elements of the socio-demography of the Turkish labour elite. Information was collected relating to gender, ethnicity, marital status and religion. The topics of ethnicity and religion are sensitive in Turkish society, leading frequently to this question being skipped by survey participants, so the response rate on these questions was significantly lower and, therefore, making conclusions is difficult.

Concerning gender, official Turkish statistics provided by the Ministry of Labour and Social Security show us that there is a serious under-representation of women in labour union structures. Women represent about $18 \%$ of the workforce (Labour Statistics 2008) and, according to different sources, between $41.60 \%$ and around $18 \%$ of unionised workers, but they have just one representative in the management council of one of the confederations. This person functions in the KESK management council as the 'women's officer'; needless to say, we thus cannot talk about gender mainstreaming in Turkish labour unions.

If we take into account the management councils of affiliated unions, we can see that there are women capable of passing on to the higher levels of union decisionmaking structures. $8.76 \%$ of the members of management committees of public sector unions are women and, for private sector unions, this percentage is $6.69 \%$ (Labour Statistics 2008).

If we focus on religion, ethnicity and marital status, the Turkish labour elite tends to approximate to the majorities in Turkish society: Turkish ethnicity; Sunni religion; and married. Only in KESK and Memur-Sen do we find a more diverse population. The response rate to these questions was so low that we are unable to provide percentages or make generalisations of any kind.

\section{The Turkish labour movement and politics}

European labour movements are often closely aligned to political parties or political currents. In Great Britain, the Labour Party was even created by the labour movement and in Belgium there are representatives of the socialist labour union on the committee of the social democrat party. In Turkey, the situation is a little more complex. It was already mentioned that Türk-Işs was created under the influence of American, apolitical unionism, but confederations such as DISK and Hak-Iss are overtly linked to the political currents of, respectively, the left and conservative-islamic side of the political spectrum. In the public sector, Kamu-Sen has a nationalist identity; Memur-Sen a religious-conservative one; and KESK an openly left-wing and activist one. This matrix of unionpolitical relations is taken for granted in the Turkish popular and academic press, but material proof is lacking. 
This research study aimed at delivering this proof by checking for union-party relationships and quantifying them via the aggregation of several pieces of data. In Table 5 , we can see the aggregated data drawn from answers to the question 'Of which party are you a member?' or, in the case of a non-response, the answer to the question 'Of which party have you been a member in the past?'. In the case of a non-response to these questions, the extent of personal mobility between union managers and the political parties is taken into account. Therefore, the response for Kamu-Sen and MemurSen is relatively high, because most interviewees answered the questions. For the other confederations, the data reflects personal mobility between parties and unions. Thus, the response rate may be lesser but the importance and viability of these cases is higher.

Looking at the results, the obvious link between Kamu-Sen and MHP is the most striking: every respondent of Kamu-Sen was a member of MHP. Next to that, we see that both Hak-İs and Memur-Sen are closely aligned to the religious side of the Turkish political spectrum, with parties such as AKP and SP. DISK managers seem to prefer a series of parties on the left (ODP, SHP, TIP) or the centre-left (CHP, DSP) of the political spectrum. Türk-Iş managers seem to prefer both left (SHP), centre-left (CHP) and far-right parties (MHP).

\begin{tabular}{|l|l|l|l|l|l|l|l|l|l|}
\hline & AKP & CHP & MHP & DSP & DTP & SHP & ODP & SP & TIP \\
\hline Türk-İs (30\%) & & $50 \%$ & $25 \%$ & & & $25 \%$ & & & \\
\hline Hak-İș (30\%) & $25 \%$ & & & & & & & $75 \%$ & \\
\hline DISK (20\%) & & $29 \%$ & & $14 \%$ & & $29 \%$ & $14 \%$ & & $14 \%$ \\
\hline Kamu-Sen (33\%) & & & $100 \%$ & & & & & & \\
\hline Memur-Sen (50\%) & $57 \%$ & $10 \%$ & $19 \%$ & & & & & $14 \%$ & \\
\hline KESK (18\%) & & & & & $50 \%$ & & $50 \%$ & & \\
\hline
\end{tabular}

Note: DSP: Demokratik Sol Parti; DTP: Demokratik Toplum Partisi; SHP: Sosyal Demokrat Halkçı Parti; ÖDP: Ozgurluk ve Dayanı̧̧ma Partisi; TIP: Turkiye Işçi Partisi

Thanks to a research study performed under the scientific co-ordination of Theo Nichols in 2010, we can compare these party preferences of confederation managers with the political orientation of rank-and-file activists. Figure 1 shows the results of Nichols' study. 


\section{Figure 1 - Political orientation of Turkish union members}

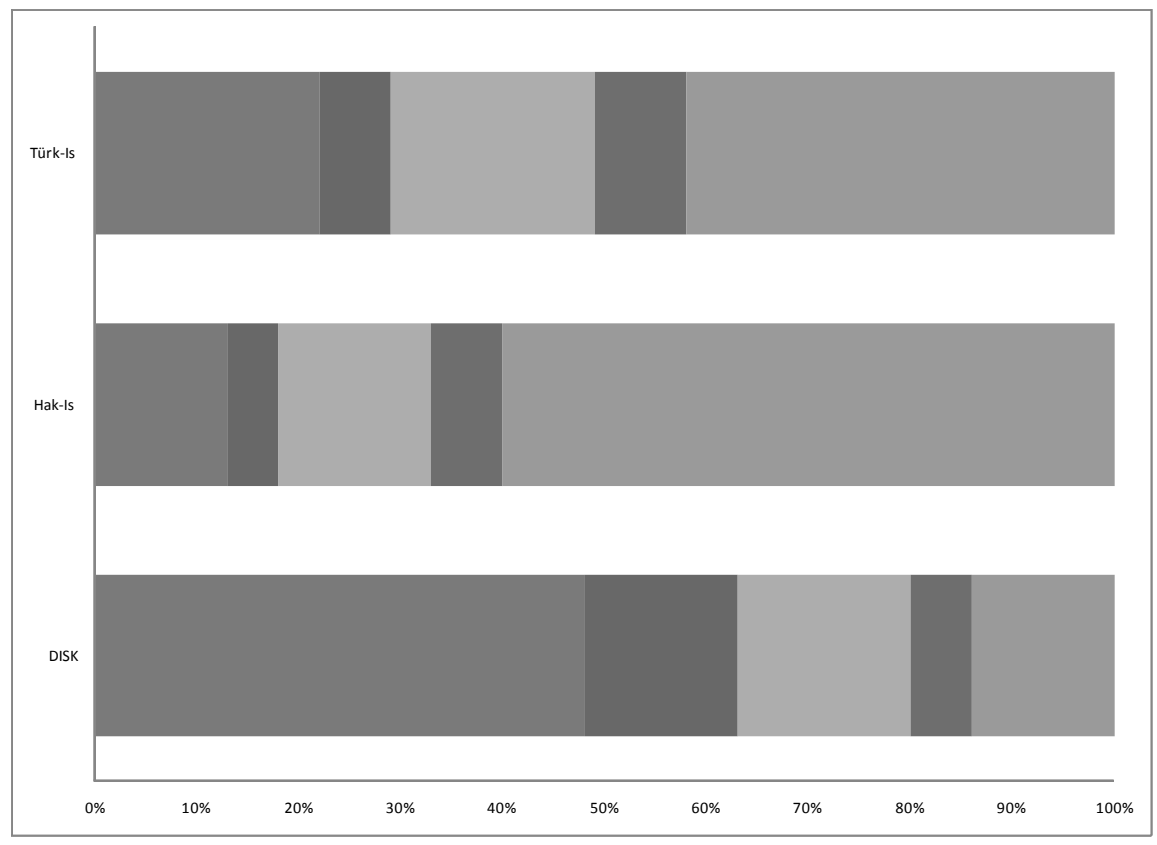

Answers on a five-point scale from Left to Right

Looking at the data, the polarisation of activists is obvious. When asked about their political orientations on a scale of 1 to 5 , from Left to Right, union activists seem to prefer the extremes rather than moderate positions. Obviously, the left-wing identity of DISK is reflected in the data, as is the conservative tendency of Hak-İş. Türk-İş activists, however, are more diverse and there is also a bigger proportion of activists that orient themselves around the centre of the political sphere.

Taking all the data together, we can conclude that the popular views as to the political orientations of the different confederations are confirmed.

\section{Limitations}

The research study collected a unique amount of information regarding the sociodemographic, political and organisational profile of the Turkish labour 'elite', but the research method and the low levels of response regarding certain themes negatively affect the value of the research.

The multi-method mode of information gathering resulted in partial and insufficient information on questions concerning ethnicity and the political affiliation of union members. Firstly, this was because the survey was not anonymous, for practical reasons. Some questions are the subject of societal taboos and so respondents did not answer 
these questions, or otherwise refused to fill in the survey in general. Secondly, the survey data was supplemented by information gathered through an analysis of the literature, but this resulted in very partial information and a changing level of valid data in response to different questions. Thirdly, even identifying the population seemed difficult as the confederations themselves could not provide us with clear and complete lists. The data was checked and double-checked in its comparisons of different sources, but there is no absolute guarantee that we identified all the members of the population.

Next to these problems regarding the information collected, methodological problems arose such as that Michels's theory does not identify any indicators or ways of measuring the key concepts in his work (maturation, professionalisation, differentiation, oligarchisation, etc.). Therefore, the research used imperfect proxies in order to approach the concepts of Michels.

\section{Conclusion}

Using Michels's (1915) theory of oligarchisation as a guideline for our research, we found that Turkish labour unions indeed showed signs of a growing institutionalisation over the years and that the eldest confederations have higher levels of stability of power than the younger ones. This confirms the basic suggestion of the theory of oligarchisation - that, with maturation, power tends to institutionalise in organisations.

Looking at whether this institutionalisation of power was also reflected in the sociodemographic characteristics of union managers, a different pattern was observed. Not only could we not observe a rise in educational levels over time in the confederations, we also saw that the eldest and most institutionalised unions tend to have managers with lower levels of education. The same can be said when analysing indicators regarding the careers of confederation managers. The eldest unions tended to show signs of careers that would be marked as 'non-professional', as they started working and were unionised at lower ages but arrived at the top of their union organisations relatively late in comparison with managers of the younger unions. On the face of it, this is contrary to Michels's affirmations but all the 'younger' unions being from public services and generally having a more educated population of members most probably explains these observations.

Regarding politics, the research collected a unique set of data on the links between unions and political parties, and observed that the popular beliefs about the ties between parties and unions can be confirmed: Türk-İş is close to the secular nationalist parties, CHP and MHP; Hak-İş is close to the muslim-conservative parties, AKP and SP; and DISK is close to a whole series of left-wing parties. This was confirmed by data gathered from union members. Notable data was found for the public service unions, with Kamu-Sen respondents all being members of MHP; KESK respondents showing affection for both left-wing as well as Kurdish parties; and Memur-Sen showing affiliations, as expected, to muslim-conservative parties.

\section{References}

14 KESK Trade Unionists Arrested (2009, 1 June), Bianet: http://bianet.org/english/ labor/114912-14-kesk-trade-unionists-arrested [last accessed 23 August 2010]. 
Alemdar, Z (2009) 'Turkish Trade Unions and the European Boomerang' European Journal of Turkish Studies 9: 1-28.

Arslan, A and G. E. Gumustekin (2004) 'Educational backgrounds of contemporary Turkish elites' International Journal of Human Sciences 1(1).

Asp, U (2002) 'The trade union situation in Turkey - an analysis' South-East Europe Review for Labour and Social Affairs 5(3): 127-136.

Blind, P. K (2007) 'A New Actor in Turkish Democratization: Labor Unions' Turkish Studies 8(2): 289-311.

Coupasson, D and S. Clegg (2006) 'Dissolving the Iron Cages? Tocqueville, Michels, Bureaucracy and the Perpetuation of Elite Power' Organization 13 (3): 319-343.

Duran, B and E. Yildirim (2005) 'Islamism, Trade Unionism and Civil Society: The Case of Hak-Is Labour Confederation in Turkey' Middle Eastern Studies 41(2): 227-247.

Katsu, S, A. Vorkink, C. Gray, S. Otoo and M. Verghis (2006) Turkey Labour Market Study Document of the World Bank: World Bank.

Labour Statistics 2008 (2009). Ankara, Turkey: Ministry of Labour and Social Security Republic of Turkey.

Leach, K. D (2005) 'The Iron Law of What Again? Conceptualizing Oligarchy across Organizational Forms' American Sociological Association 3: 312-337.

McClelland, J. S (1996) A History of Western Political Thought London: Routledge.

Michels, R (1915) Political Parties. A sociological study of the Oligarchical Tendencies of Modern Democracy (trans. P. E. Cedar) Kitchener.

Oke, M. Kemal (2006) Capacity building for social dialogue in Turkey European Foundation for the Improvement of Living and Working Conditions, November.

Rychly, L and M. Vylitova (2005) National Social Dialogue on Employment Policies in Europe Social Dialogue, Labour Law and Labour Administration Department, ILO: Geneva.

Sural, A. N (2007) 'A Pragmatic Analysis of Social Dialogue in Turkey’ Middle Eastern Studies 43(1): 143-152.

Sural, A. N (2006) 'Evolving Structure of Collective Bargaining in Turkey (1990-2005)' Middle Eastern Studies 42(6): 965-996.

Trade Unions in Turkey (1998) Friedrich-Ebert-Stiftung paper, available at: http:// www.fes.de/fulltext/bueros/istanbul/00253toc.htm [last accessed 15 February 2010].

Turk-Is baskanlik yarisini Kumlu kazandi (2007) Radikal 10 December.

Uçkan, B (2007) 'From the perspective of EU integration: trade union rights in Turkey' South-East Europe Review for Labour and Social Affairs 10(4): 107-126. 
Voss, K and R. Sherman (2000) 'Breaking the Iron Law of Oligarchy: Union revitalization in the American Labor Movement' American Journal of Sociology 106(2): 303-349.

Yildirim, E and S. Calis (2006) Transformation of Turkish Social Policy Making on the Road to Brussels? The Case of Social Dialogue, p. 12, Ankara: METU.

Yildirim, E, S. Calis and A. Benli (2008) 'Turkish Labour Confederations and Turkey's Membership of the European Union' Economic and Industrial Democracy 29(3): 362-387.

Zurcher, E. J (2006) Een geschiedenis van het moderne Turkije Amsterdam: SUN [translation of: Turkey. A modern history, $3^{\text {rd }}$ revised edition, London: I. B. Tauris]. 